\title{
EFFECTS OF AGE UPON THE MOBILITY OF HUMAN FINGER JOINTS
}

\author{
BY \\ C. H. BARNETT* AND A. F. COBBOLD \\ From the Departments of Anatomy and Physiology, University of Tasmania, Hobart
}

Few measurements have been made of the frictional forces within living joints. Barnett and Cobbold (1962) recorded that the coefficient of friction at the distal interphalangeal joint of the middle finger in six healthy adults could be as low as 0.0075 , a figure of the same order as that in excised joints (Jones, 1936; Charnley, 1959). Rydell (1965) measured, in a patient fitted with a hip prosthesis, the coefficient of friction between the artificial femoral hip and the intact acetabulum; he gave a figure $0.021 \pm 0.0014$. The present paper is concerned with the variation observed in the coefficient of friction, as reflected by joint mobility, among individuals of different ages.

\section{Material and Methods}

The frictional forces in the finger joints of 111 healthy adults, 74 males and 37 females, have been measured using the apparatus previously described (Barnett and Cobbold, 1962). This consists of a pendulum that is attached to the end of the middle finger and is set swinging, the other joints being maintained in a position that throws the flexor and extensor tendons out of action. The rate of decay of amplitude of the freely swinging pendulum enables the forces restricting the joint mobility to be calculated. As previously shown, the coefficient of friction in synovial joints is not independent of the load that is borne. To allow accurate comparison between subjects, each finger joint tested carried the same weight, approximately $430 \mathrm{~g}$. The friction depends also upon the radius of curvature of the head of the middle phalanx measured in the sagittal plane, but it was decided, after examining a number of lateral radiographs of adult fingers, to assume a radius of $4 \mathrm{~mm}$. for each joint. The inaccuracy so introduced was not great and affected equally people at all ages.

To the engineer, the term "coefficient of friction" is inappropriate because there are several forces that reduce joint mobility apart from the friction between the articulating surfaces-for example, the tension within the joint capsule and the stiffness of the overlying skin-but this term has become the accepted one in the medical literature and will be used here. Especially in older

* Present address: Anatomy Department, St. Thomas's Hospital Medical School, London, S.E.1. women, the distal joints of the fingers often show arthritic changes. Any person exhibiting Heberden's nodes, other swelling or deformity, or a history of pain, trauma, or swelling of the fingers was excluded from the present series.

\section{Results}

The calculated coefficients of friction are shown in the Table, together with the means and standard deviations.

No statistically significant difference was found between the joint mobility of males and females in this small series, and for that reason the findings in both sexes are considered together.

The results are recorded in the Table by decades.

The group representing the second decade comprised sixteen university students, none below the age of 17 years. In the older age group there were two females aged 90 and for convenience they are included in the ninth decade.

The results are shown graphically in Fig. 1. It may be seen that the mean coefficients of friction increase with age, but there is a wide scatter about the mean.

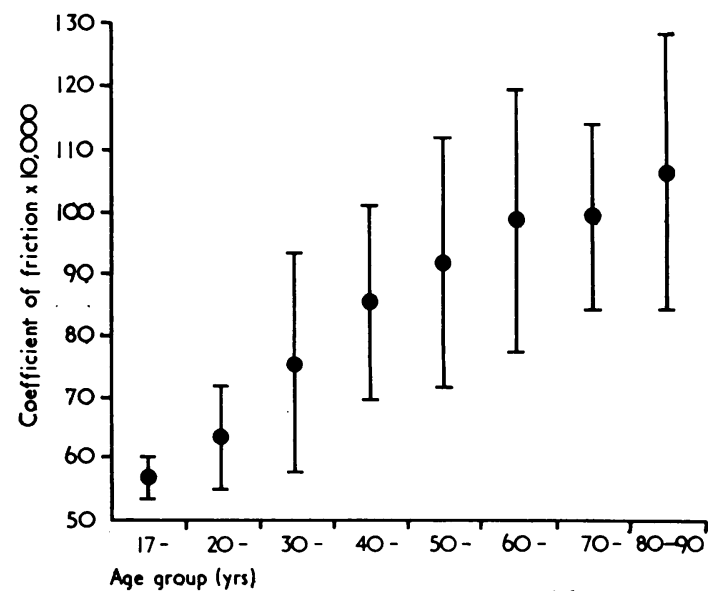

Fig. 1.-Mean coefficients of friction recorded in eight age groups. The means range from 0.00568 in the second decade to 0.0106 in the ninth. The 95 per cent. confidence limits are shown. 
COEFFICIENTS OF FRICTION (C.F.) WITHIN FINGER JOINTS OF 111 HEALTHY SUBJECTS, BY DECADES OF AGE

\begin{tabular}{|c|c|c|c|c|c|c|c|c|c|c|c|c|c|c|c|}
\hline \multicolumn{2}{|c|}{ 2nd decade } & \multicolumn{2}{|c|}{ 3rd decade } & \multicolumn{2}{|c|}{ 4th decade } & \multicolumn{2}{|c|}{ 5th decade } & \multicolumn{2}{|c|}{ 6th decade } & \multicolumn{2}{|c|}{ 7th decade } & \multicolumn{2}{|c|}{ 8th decade } & \multicolumn{2}{|c|}{ 9th decade } \\
\hline Age & C.F. & Age & C.F. & Age & C.F. & Age & C.F. & Age & C.F. & Age & C.F. & Age & C.F. & Age & C.F. \\
\hline $\begin{array}{l}18 \\
19 \\
19 \\
19 \\
19 \\
17 \\
17 \\
17 \\
19 \\
19 \\
19 \\
19 \\
19 \\
18 \\
17 \\
19\end{array}$ & $\begin{array}{l}0.0057 \\
0.0050 \\
0.0049 \\
0.0060 \\
0.0060 \\
0.0065 \\
0.0047 \\
0.0056 \\
0.0057 \\
0.0061 \\
0.0057 \\
0.0074 \\
0.0050 \\
0.0052 \\
0.0057 \\
0.0056\end{array}$ & $\begin{array}{l}23 \\
26 \\
22 \\
24 \\
23 \\
23 \\
25 \\
21 \\
20 \\
26 \\
20 \\
21 \\
20 \\
21 \\
28 \\
23\end{array}$ & $\begin{array}{l}0.0047 \\
0.0065 \\
0.0047 \\
0.0087 \\
0.0035 \\
0.0057 \\
0.0074 \\
0.0096 \\
0.0050 \\
0.0071 \\
0.0057 \\
0.0047 \\
0.0045 \\
0.0071 \\
0.0078 \\
0.0086\end{array}$ & $\begin{array}{l}32 \\
33 \\
35 \\
31 \\
33 \\
32 \\
34 \\
35\end{array}$ & $\begin{array}{l}0.0061 \\
0.0064 \\
0.0074 \\
0.005 \\
0.0065 \\
0.013 \\
0.010 \\
0.0057\end{array}$ & $\begin{array}{l}49 \\
48 \\
49 \\
41 \\
41 \\
42 \\
46 \\
43 \\
42 \\
41 \\
42 \\
43 \\
40 \\
41 \\
43 \\
43 \\
48 \\
49 \\
42\end{array}$ & $\begin{array}{l}0.0038 \\
0.0068 \\
0.0087 \\
0.0047 \\
0.0061 \\
0.013 \\
0.0047 \\
0.0049 \\
0.0061 \\
0.0075 \\
0.014 \\
0.017 \\
0.013 \\
0.0096 \\
0.0074 \\
0.011 \\
0.0104 \\
0.0074 \\
0.0086\end{array}$ & $\begin{array}{l}59 \\
51 \\
51 \\
52 \\
57 \\
56 \\
53 \\
53 \\
50 \\
51 \\
54 \\
54 \\
55\end{array}$ & $\begin{array}{l}0.0065 \\
0.012 \\
0.0060 \\
0.0074 \\
0.0065 \\
0.0052 \\
0.014 \\
0.0063 \\
0.0065 \\
0.018 \\
0.013 \\
0.010 \\
0.0074\end{array}$ & $\begin{array}{l}69 \\
68 \\
60 \\
68 \\
65 \\
66 \\
68 \\
67 \\
67 \\
63 \\
66 \\
60 \\
62 \\
64 \\
65 \\
65\end{array}$ & $\begin{array}{l}0.0081 \\
0.0074 \\
0.0065 \\
0.0087 \\
0.016 \\
0.012 \\
0.0074 \\
0.010 \\
0.0065 \\
0.0052 \\
0.0081 \\
0.017 \\
0.013 \\
0.014 \\
0.0086 \\
0.010\end{array}$ & $\begin{array}{l}\mathbf{7 8} \\
\mathbf{7 1} \\
\mathbf{7 2} \\
\mathbf{7 6} \\
\mathbf{7 4} \\
\mathbf{7 3} \\
\mathbf{7 7} \\
\mathbf{7 7} \\
\mathbf{7 1} \\
\mathbf{7 1} \\
\mathbf{7 7} \\
\mathbf{7 8}\end{array}$ & $\begin{array}{l}0.0068 \\
0.0108 \\
0.017 \\
0.012 \\
0.013 \\
0.014 \\
0.013 \\
0.013 \\
0.0057 \\
0.0074 \\
0.0087 \\
0.0104\end{array}$ & $\begin{array}{l}90 \\
81 \\
81 \\
89 \\
81 \\
85 \\
80 \\
81 \\
81 \\
89 \\
90\end{array}$ & 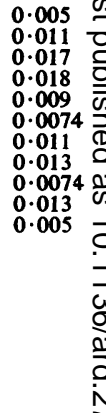 \\
\hline \multicolumn{2}{|c|}{$\begin{array}{l}\text { Mean }=10^{-4} \times \\
56.8 \pm \text { s.d. } 6.48\end{array}$} & \multicolumn{2}{|c|}{$\begin{array}{l}\text { Mean }=10^{-4} \times \\
63 \cdot 3 \pm \text { s.d. } 17 \cdot 3\end{array}$} & \multicolumn{2}{|c|}{$\begin{array}{l}\text { Mean }=10^{-4} \times \\
75 \cdot 1 \pm \text { s.d. } 25 \cdot 0\end{array}$} & \multicolumn{2}{|c|}{$\begin{array}{l}\text { Mean }=10^{-4} y \\
85 \cdot 3 \pm \text { s.d. } 33 \cdot 6\end{array}$} & \multicolumn{2}{|c|}{$\begin{array}{l}\text { Mean }=10^{-4} \times x \\
91 \cdot 4 \pm \text { s.d. } 37 \cdot 9\end{array}$} & \multicolumn{2}{|c|}{$\begin{array}{l}\text { Mean }=10^{-4} \times \\
98 \cdot 8 \pm \text { s.d. } 41 \cdot 9\end{array}$} & \multicolumn{2}{|c|}{$\begin{array}{l}\text { Mean }=10^{-4} \times \\
99 \cdot 1 \pm \text { s.d. } 26 \cdot 1\end{array}$} & \multicolumn{2}{|c|}{$\begin{array}{l}\text { Mean }=10^{-4} \times \\
106 \cdot 2 \pm \text { s.d. } 36 \cdot 1\end{array}$} \\
\hline
\end{tabular}

There is a suggestion of a bimodal distribution in older joints. Fig. 2 shows three histograms recording the frictional forces in 32 subjects aged 17 to 29 years, forty aged 30 to 59 years, and 39 aged 60 to 90 years. It appears that the higher means in the second and third age groups are due in part to the existence of a small number of people with joints much stiffer than in the young. However, it should be noted that only three of the 39 finger joints tested in the third age group had coefficients of friction below 0.006 , and the mean coefficient in
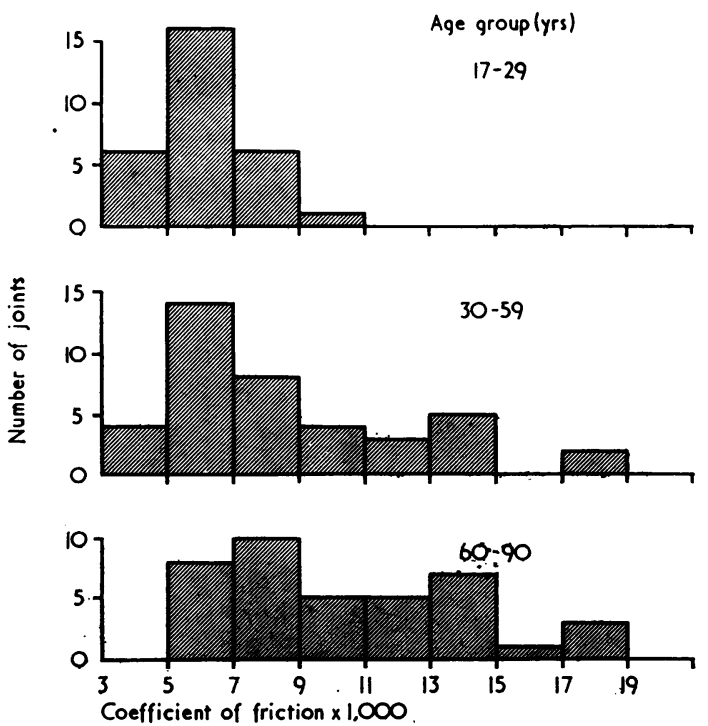

Fig. 2.-Histograms showing distribution of subjects with different coefficients of friction, arranged in three age groups. the elderly differs highly significantly $(P<0.01)$ from that found in the university students.

\section{Discussion}

Before the measurements were made, it had been assumed that, in the elderly, joints would have afa higher coefficient of friction than in the young However, the present findings indicate that tho finger joints of healthy octogenarians have, of average, a coefficient of friction only twice that in university students. In some old people, indeed the fingers remain almost as mobile as in youth.

A patient's complaint of joint stiffness must ofte arise from extra-articular factors, notably changes ii muscles and tendons (Wright and Johns, 1960) The apparatus used in the present study eliminates these factors, so the differences in finger mobility. that have been recorded must be due to age changes in the synovial fluid, the articular cartilage, or the surrounding tissues, especially the ligaments.

With increasing years synovial fluid tends to be less viscous (Jebens and Monk-Jones, 1959) an more newtonian in its properties (Sokoloff, personat communication), thus becoming a less effective joinf lubricant. As articular cartilage ages, many of the superficial chondrocytes die (Barnett and StockwelN 1966) and the content of chondroitin sulphat which is responsible for the resilience of healthy cartilage, is reduced. In addition, the articular capsule and surrounding ligaments are known to thicken with increasing age. Probably all threot factors play a part in reducing finger-joint mobilit产 in older persons. 


\section{Summary}

The coefficient of friction within the distal interphalangeal joint of the middle finger was measured in each of 111 healthy adults whose ages ranged from 17 to 90 years. The mean coefficient in the elderly was significantly raised, but there was a wide scatter and some old people had finger joints as mobile as in the second decade of life. Since the apparatus used eliminated the damping effect of muscles and tendons, any reduced joint mobility observed must depend mainly on age changes in the synovial fluid, articular cartilage, or joint ligaments.

This work was supported by a grant, Number 65/ 15306, from the Australian Research Grants Committee. We are indebted to Mr. A. J. Trebilcock for permission to examine patients at St. John's Park Hospital, Hobart, and to Mr. E. E. Garrard and Mr. D. P. Smith for technical assistance.

\section{REFERENCES}

Barnett, C. H., and Cobbold, A. F. (1962). J. Bone Jt Surg., 44B, 662 (Lubrication within living joints).

— and Stockwell, R. A. (1966). In "Modern Trends in Rheumatology", ed. A. G. S. Hill, p. 253. Butterworths, London.

Charnley, J. (1959). "The Lubrication of Animal Joints", in "Symposium on Biomechanics", p. 12. Institution of Mechanical Engineers, London.

Jebens, E. H., and Monk-Jones, M. E. (1959). J. Bone Jt Surg., 41B, 388 (On the viscosity and pH of Synovial Fluid and the $\mathrm{pH}$ of Blood).

Jones, E. S. (1936). Lancet, 1, 1043 (Joint lubrication).

Rydell, N. (1965). "Forces in the Hip-joint", in "Biomechanics and Related Bio-engineering Topics", Proceedings of a Symposium held at Glasgow, 1964, ed. R. M. Kenedi, p. 357. Pergamon, Oxford.

Sokoloff, L. (1965). Personal communication.

Wright, V., and Johns, R. J. (1960). Arthr. and Rheum., 3, 328 (Observations on the measurement of joint stiffness).

Les effets de l'age sur la mobilité des articulations digitales humaines

\section{RÉSUMÉ}

On détermina le coefficient de friction dans l'articulation interphalangienne distale du doigt moyen chez 11 adultes sains dont l'âge s'étendait de 17 à 90 ans. On trouva le coefficient moyen appréciablement élevé chez les personnes âgées, mais la dispersion fut considérable et les doigts de quelques vieillards furent aussi mobiles que ceux des jeunes gens. Etant donné que l'appareil employé éliminait l'effet freinant des muscles et des tendons, toute réduction observée de la mobilité articulaire peut être attribuée aux altérations, dues à l'âge, dans le liquide synovial, le cartilage articulaire ou les ligaments articulaires.
Los efectos de la edad sobre la movilidad de las articulaciones digitales humanas

\section{Sumario}

Se determinó el coeficiente de fricción en la articulación interfalangiana distal del dedo medio en 11 adultos sanos de edades entre 17 y 90 años. El coeficiente medio en los ancianos fué apreciadamente elevado pero la dispersión fué considerable y los dedos de algunos ancianos fueron tan móviles como los de personas jóvenes. El aparato empleado eliminaba el efecto frenante de los músculos y de los tendones, de modo que la reducción observada de la movilidad articular se puede atribuir a cambios, debidos a la edad, en el líquido sinovial, el cartílago articular o los ligamentos articulares. 